\begin{tabular}{ccc}
\hline International Journal of Current Research in \\
Biosciences and Plant Biology \\
Volume $4 \cdot$ Number 8 (August-2017) $\bullet$ ISSN: 2349-8080 (Online) \\
PUCLLLENT
\end{tabular}

\title{
Impact of Propiconazole on Soil Enzymes Activity in Tropical Red and Paddy Soils
}

\author{
Praveen Satapute ${ }^{1}$ and Basappa Kaliwal ${ }^{1,2} *$ \\ ${ }^{I}$ Department of Microbiology and Biotechnology Karnatak University, Dharwad, Karnataka, India \\ ${ }^{2}$ Department of Microbiology and Biotechnology, Davangere University, Davangere, Karnataka, India
}

*Corresponding author: Department of Microbiology and Biotechnology Karnatak University, Dharwad, Karnataka, India

\begin{abstract}
The use of triazole fungicide as agrochemicals into soil leading to many long lasting effects on the microbes present in the soil environment which indirectly affecting the soil health, the current work evaluates the impact of propiconazole on cellulase and invertase activities in red loam soil of groundnut (Arachis hypogaea L.) and paddy soil (Oryza sativa). In vitro experiment was conducted to evaluate the effect of propiconazole on their application rates $(1.0,2.5,5.0,7.5$ and $10.0 \mathrm{~kg} / \mathrm{ha})$ on cellulase and invertase. The period of experimental set up was 10,20,30 and 40 days under the in vitro conditions. The results show that propiconazole was found stimulatory for the activities to the cellulase and invertase at lower application rates in both soils after 10 days of incubation period and an outstanding increase in the activity of cellulase and invertase was observed at the application rate 5.0 and $2.5 \mathrm{~kg} / \mathrm{ha}$ respectively. Conversely, the comparable trend was observed after 20 days of incubation. The higher application rates $(7.5$ and $10.0 \mathrm{~kg} / \mathrm{ha})$ were found toxic to activity of cellulase and invertase in both red loamy and paddy soil. However, the results of the present investigation suggest that, recommended application rates of propiconazole have greater impact on the enzyme activity in the soil and the application of higher doses and regular contact of propiconazole will cause the harmful effect on enzyme activity in red loamy and paddy soil.
\end{abstract}

\section{Article Info}

Accepted: 31 July 2017

Available Online:06 August 2017

\section{Keywords}

Arachis hypogaea $\mathrm{L}$.

Cellulase activity

Invertase

Oryza sativa

Propiconazole

Triazole fungicide

\section{Introduction}

Agricultural production in the Republic of India magnified dramatically throughout the last four decades, resulting in an era of food self-reliance and this can play a key role in the growth of Indian economy. Significantly, this growth signifies the assembly of 28 share of the gross domestic product (GDP) and up to date exceptional growth was achieved throughthe uptake of newer technologies within the sort of high yielding crop varieties, chemical fertilizers and pesticides. It's additionally vital to understand that Indian agriculture has advanced protracted manner from an amount of frequent droughts and susceptibility to food scarcities (Abrol and Sangar, 2000).

Enzymes are the active agents for life courses, similarly, in the soil they are recognized to show a considerable part in preserving the soil healthiness and its environment. The activity of enzyme in the 
soil is generally of microbial origin, being resulting from cell-associated or free enzymes and intracellular. Meanwhile, a soil health is maintained with equal contribution of physical, chemical and biological components (Ellert et al., 1997). Cellulase is a one of the important enzyme in the carbon cycle and it specifically acts on the $\beta-1,4$-glucan bonds in cellulase, and it is a rich carbonaceous polymer in the environment, Therefore, cellulase involved in the main routes of the carbon cycle (White 1982; Mallik and Sharma, 2002). Apparently, Invertase catalyses the hydrolysis of sucrose to fructose and glucose, moreover and is extensively dispersed in microorganisms, plants and animals (Alef and Nannipieri, 1995).

The toxicant impact of the many fungicides is still unknown, Shukla (2000) has demonstrated the toxicant impact of fungicides on microbialpopulation and impact on enzyme activity, it's clear that once the antimycotic agents are in contact with soil can end up in the modification within the activity of soil enzymes. As a result, the considerably soil catalyst activity is down (Shetty and Magu, 1998). Triazole area unit, the key cluster of fungicides they're used wide owing to their versatile nature and general action. In spite of their wide unfold usage, the toxicity analysis weren't comprehensively assessed (Filipov and Lawrence, 2001).

Wightwick et al. (2010) reports regarding environmental risks of triazole fungicides on agriculture production systems, it provides clear clues that triazole contaminations will result in the dramatic decrease within the production of the agricultural merchandise. Propiconazole could be a triazole foliar antimycotic agent, employed in the agriculture fields. The yearly intake of this antimycotic agent is regarding $7373 \mathrm{~g}$ ai./ha. It's one amongst the leading triazole antimycotic agent within the agriculture field in the India. Propiconazole is used to protect the crops of wheat, rice, tea, banana and etc. against the diseases like karnal bunt, brown rust, black rust, yellow rust, sheath blight, blister blight and etc. The toxicity assessment isn't clearly studied. However, antecedent few researchers studied the impact of propiconazole on the soil microbial population and its impact on crop yield (Elmholt, 1991; Elmholt, 1992; Yen et al., 2009). Hence, the current investigation was undertaken to check the impact of propiconazole antimycotic agent on soil enzyme activity.

\section{Materials and methods}

\section{Soil used for the enzymes activity studies}

To know the impact of propiconazole on soilenzyme activity, two different soils were chosen for this study, red sandy loamy soil from the ground nut cultivated field and paddy soil from the Dharwad district, Karnataka, India, it was collected from the upper layer $(0-10 \mathrm{~cm})$ wherever the microorganism population is rich with high enzyme activity. Both the soil was aseptically brought to the laboratory in sterile baggage. Soils were mixed completely for the preparation of homogeneous composite mixture; all the debris and plant materials were removed. Further, the soil samples were sieved through $2 \mathrm{~mm}$ sieve and dried at $30^{\circ} \mathrm{C}$ in hot air oven (JSR). Air dried soil samples were stored in the $4^{\circ} \mathrm{C}$ before analysis.

\section{Fungicide used for the soil enzymes activity}

To evaluate the impact of propiconazole on the soil enzyme activities, Tilt 25 EC (propiconazole antimycotic $25^{\text {th }}$ blended grade, Syngenta, India) was procured from native pesticide dealers of Dharwad. The emulsified grade of propiconazole fungicide dissolved within the distilled water 25ml: $100 \mathrm{~L}$ ratio for the further use.

\section{Physicochemical properties of soils}

The content of sand, silt and clay as mineral matter within the red loamy was evaluated by the subsequent method of Alexander (1977). The amount of nitrogen content within the soil was analyzed by Micro-Kjeldhal methodology (Jackson, 1971). The percentage of water holding capability of the soil throughout the experiment was calculated according to the Johnson and Ulrich (1960). Using the digital $\mathrm{pH}$ scale meter, the $\mathrm{pH}$ of soil was determined by the quantitative relation of $1: 1.25$ of soil to water.

\section{Soil samples preparation}

A homogenate composite mixture of soil samples was weighed specifically 5 grams and dispersed into the clean sterile test tube $(25 \times 150 \mathrm{~mm})$. Antecedently prepared stock solutions of commercial grade propiconazole antimycotic was added at the rate of 10 , $25,50,75$ and $100 \mu \mathrm{g} / \mathrm{g}$, which are equal to the rate of field application i.e. $1,2.5,5,7.5$ and $10 \mathrm{~kg} / \mathrm{ha}$, 
respectively. Antimycotic content tube was considered as the positive tubes, whereas, the tubes only with soil however not antimycotic were treated as the control tubes. All the samples were mixed completely for the higher circulation of fungicide. For all the treatments, three sets of experiments were maintained throughout the 40 days of study at the $28 \pm 2^{\circ} \mathrm{C}$ in a humid atmosphere (75-80\% relative humidity).

\section{Cellulase activity (EC 3.2.1.4.)}

With the intention of determining the cellulase enzyme activity of the soils, at the preferred intervals, the method described by the Srinivasulu and Rangaswamy (2006) was adopted for the analysis. All the samples were extracted using distilled water for the analysis of enzyme activity. The extracts were transferred to the Erlenmeyer flasks and to prevent the enzyme activity the inhibitor was added and incubated for the 30 minutes, moreover $1 \%$ of $10 \mathrm{ml}$ carboxy methyl cellulose was used as the substrate followed by the $10 \mathrm{ml}$ of acetate buffer were added and incubated for the $24 \mathrm{hrs}$ to known the reducing sugar concentrations within the extracted samples (Deng and Tabatabai, 1994). In the other hand, the activity of cellulase was evaluated at 10,20, 30 and 40 days of incubation at $28 \pm 2{ }^{\circ} \mathrm{C}$ with higher than mentioned particular enzyme substrate.

\section{Invertase activity (EC 3.2.1.26)}

The operating method for the assay of invertase was developed by the Cole (1977) and followed by the Tu (1981). The fractions of soil samples were transferred to the Erlenmeyer flasks and $1 \mathrm{ml}$ of resolvent was additional to flasks to arrest the enzyme activities, after the desired 15 minutes of incubation time. A $18 \mathrm{mM}$ of $6 \mathrm{ml}$ sucrose was added to the actual soil samples and incubated for the 24 and $28 \mathrm{hrs}$, the test samples were filtered by the Whatman filter paper no. 1 and obtained filtrates were analyzed for the assessing the concentration of glucose present in the soil samples by the Nelson Somogyi methodology (Nelson, 1944) in Hitachi U2900 spectrophotometer. In the other side, the enzyme activity of the invertase was assayed at 10, 20, 30 and 40 days of the time period with appropriate enzyme substrate.

\section{Statistical analysis}

All the experiments were carried in a triplicates and the rate of concentrations of cellulase and the amylase deliberate based on the soil weight. Obtained information was assessed by using one way ANOVA with the Post hoc DUNCAN'S test by using the SPSS 20 statistical data software package, all the data were analyzed at $p \leq 0.05$.

\section{Results}

\section{Physicochemical properties of soils}

In our previous study, the physicochemical properties of paddy soil were found to be saline in nature and electric conductivity was $291 \mathrm{dS} / \mathrm{m}$ (Satapute and Kaliwal, 2016). Similarly, red loamy soil of the groundnut was having the $\mathrm{pH}$ of 6.7 and it was measured during the preparation of 1:1.25 slurry of water and soil. Additionally, the electric conductivity $0.202 \mathrm{dS} / \mathrm{m}$ (Table 1 ).

Table 1. Physicochemical properties of soil.

\begin{tabular}{ll}
\hline Nutrition & Red sandy loam soil \\
\hline $\mathrm{pH}$ & 6.7 \\
Electric conductivity dS/m & 0.202 \\
Organic carbon \% & 0.72 \\
Nitrogen $\mathrm{kg} / \mathrm{ha}$ & 201 \\
Phosphorus kg/ha & 92 \\
Potassium $\mathrm{kg} / \mathrm{ha}$ & 583 \\
Sulfur $\mathrm{kg} / \mathrm{ha}$ & 41.02 \\
Calcium me/100g & 31.9 \\
Magnesium me/100g & 5.01 \\
Zinc (ppm) & 0.76 \\
Iron (ppm) & 1.92 \\
Magnesium (ppm) & 0.30 \\
Cupper $(\mathrm{ppm})$ & 0.82 \\
Sand $(\%)$ & 50.21 \\
Silt $(\%)$ & 32.53 \\
Clay $(\%)$ & 18.93 \\
\hline
\end{tabular}




\section{Cellulase activity (EC 3.2.1.4)}

Cellulase enzyme activity was increased in all the concentrations with the exception of $10 \mathrm{~kg} / \mathrm{ha}$ and the impact of all the application rates of propiconazole on the cellulase enzyme activity is illustrated in the Table 2.

Explaining the activity of the enzyme under desired application rates incubated for the $24 \mathrm{hrs}$ extracted after 10 days.

Table 2. Activity of cellulose ( ${ }^{*} \mu \mathrm{g}$ of glucose/gram) under the impact of propiconazole in red loamy and paddy soil for $24 \mathrm{hrs}$ after 10 days.

\begin{tabular}{lll}
\hline Concentrations of propiconazole (kg/ha) & Propiconazole (Tilt) & Paddy soil \\
\cline { 2 - 3 } & Red loamy Soil & $388 \pm 5.0442^{\mathrm{f}}$ \\
\hline 0 & $345 \pm 2.6034^{\mathrm{e}}$ & $416 \pm 6.2271^{\mathrm{d}}$ \\
1 & $373 \pm 7.0000^{\mathrm{d}}$ & $522 \pm 2.4037^{\mathrm{c}}$ \\
2.5 & $503 \pm 7.0946^{\mathrm{c}}$ & $681 \pm 2.0816^{\mathrm{a}}$ \\
5.0 & $647 \pm 2.3333^{\mathrm{a}}$ & $546 \pm 4.0414^{\mathrm{b}}$ \\
7.5 & $530 \pm 5.5075^{\mathrm{b}}$ & $392 \pm 4.7022 \mathrm{e}$ \\
\hline 10.0 & $340 \pm 3.3829^{\mathrm{f}}$ & \\
\hline
\end{tabular}

All column is mean \pm S.E. for respected concentrations in every group; column sharing the different letters $(a, b, c, d, e$ and $f)$ are significantly different with each other $(p \leq 0.05)$.

It was also noticed that, the stimulatory activity of the cellulase enzyme in paddy and red loamy soil was found at the $5 \mathrm{~kg} / \mathrm{ha}$. Moreover, in both the type of soil cellulase activity was significantly increased. While comparing the obtained activity with control it was unveiled that, soil treated with the 1 and 2.5 $\mathrm{Kg} / \mathrm{ha}$ of fungicide enhances the activity of cellulase after 10 days. In contrast, 7.5 and $10 \mathrm{~kg} / \mathrm{ha}$ treated soil types were significantly decreases in the activity of cellulase. On the other hand, the stimulatory application rate $5 \mathrm{~kg} / \mathrm{ha}$ was induces activity of cellulase after the $10^{\text {th }}$ days. Additionally, in $20^{\text {th }}$ day the activity was found to be highest in the both paddy and red loamy soil. Whereas, on the $30^{\text {th }}$ and $40^{\text {th }}$ day, the activity was decreased and importantly the decline stage of enzyme activity in both the soils were considered to be between $30-40^{\text {th }}$ days (Fig. $1 \mathrm{~A}$ and $1 \mathrm{~B})$.
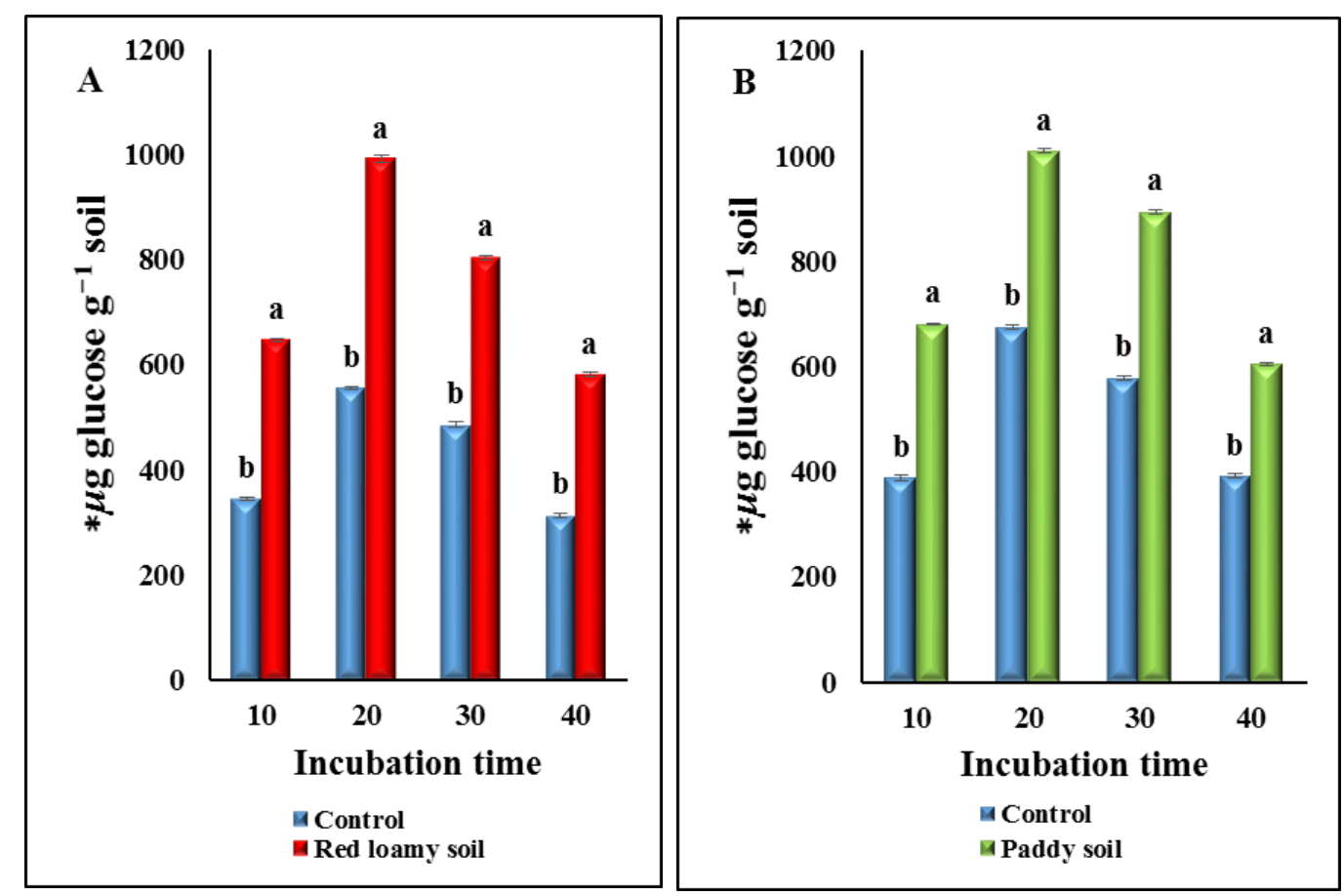

Fig. 1: Influence of propiconazole at $5.0 \mathrm{~kg} / \mathrm{ha}$ on cellulose activity on Red loamy soil of ground nut (A) and paddy soil (B) * $\mu$ g of glucose/gram soil formed after $24 \mathrm{hrs}$ with $1 \%$ carboxy methyl cellulase after 10, 20,30, and 40 days. The data are the means \pm S.E. for each incubation period. 


\section{Invertase activity (EC 3.2.1.26)}

In the present investigation of invertase activity in paddy and red loamy soils. Showed the induced increment in the concentration of invertase in application rates of 1 and $2.5 \mathrm{~kg} / \mathrm{ha}$. Whereas, the decline phase of enzyme activity was initiated from the $5 \mathrm{~kg} / \mathrm{ha}$, similarly in the 7.5 and $10 \mathrm{~kg} / \mathrm{ha}$ the liberal reduction in the enzyme activity was found for $24 \mathrm{hrs}$ and $48 \mathrm{hrs}$ after 10 days of incubation. Moreover, the stimulatory impact was occurred at $2.5 \mathrm{~kg} / \mathrm{ha}$ in both types of soils (Table 3 and 4). In comparison with control the progressive increment of invertase activity was obtained at the rate of 1 and 2.5 $\mathrm{kg} / \mathrm{ha}$. But, the soil types treated with $10 \mathrm{~kg} / \mathrm{ha}$ were significantly decreased in the enzyme activity than the control. On the other hand, the stimulatory application rate $2.5 \mathrm{~kg} / \mathrm{ha}$ was induces activity of invertase after 10 days incubation period. Furthermore, in the $20^{\text {th }}$ day the activity was found to be maximum in the both paddy and red loamy soil. However, after the 20 days of incubation the activity was lowered and it was important to note that, the decline period of invertase enzyme activity in the both soils were considered to be between $30-40^{\text {th }}$ days (Fig. 2A and 2B).

Table 3. Activity of invertase $\left({ }^{*} \mu \mathrm{g}\right.$ of glucose/gram) under the impact of propiconazole in red loamy and paddy soil for $24 \mathrm{hrs}$ after 10 days.

\begin{tabular}{lll}
\hline $\begin{array}{l}\text { Concentrations of propiconazole } \\
\text { (kg/ha) }\end{array}$ & Propiconazole (Tilt) & \\
\cline { 2 - 3 } & Red loamy Soil & Paddy soil \\
\hline 0 & $799 \pm 2.4037^{\mathrm{e}}$ & $776 \pm 2.8480^{\mathrm{e}}$ \\
1 & $894 \pm 4.0414^{\mathrm{d}}$ & $979 \pm 2.0816^{\mathrm{c}}$ \\
2.5 & $1054 \pm 5.8972^{\mathrm{a}}$ & $1142 \pm 4.0960^{\mathrm{b}}$ \\
5.0 & $1001 \pm 3.4801^{\mathrm{b}}$ & $1115 \pm 5.1747^{\mathrm{a}}$ \\
7.5 & $970 \pm 4.9103^{\mathrm{c}}$ & $809 \pm 5.5075^{\mathrm{d}}$ \\
10.0 & $770 \pm 4.3589^{\mathrm{f}}$ & $737 \pm 3.3829^{\mathrm{f}}$ \\
\hline
\end{tabular}

All column is mean \pm S.E. for respected concentrations in every group; column sharing the different letters (a,b,c,d,e and f) are significantly different with each other $(P \leq 0.05)$.

Table 4. Activity of invertase ( ${ }^{*} \mu \mathrm{g}$ of glucose/gram) under the impact propiconazole in red loamy and paddy soil for $48 \mathrm{hrs}$ after 10 days.

\begin{tabular}{lll}
\hline $\begin{array}{l}\text { Concentrations of propiconazole } \\
\text { (kg/ha) }\end{array}$ & $\begin{array}{l}\text { Propiconazole (Tilt) } \\
\text { Red loamy soid }\end{array}$ & Paddy soil \\
\hline 0 & $910 \pm 3.7564^{\mathrm{e}}$ & $890 \pm 1.2018^{\mathrm{e}}$ \\
1 & $1003 \pm 2.7284^{\mathrm{c}}$ & $993 \pm 2.403^{\mathrm{c}}$ \\
2.5 & $1040 \pm 0.8819^{\mathrm{a}}$ & $1213 \pm 8.3266^{\mathrm{a}}$ \\
5.0 & $1002 \pm 7.1248^{\mathrm{b}}$ & $1116 \pm 3.1798^{\mathrm{b}}$ \\
7.5 & $970 \pm 1.5275^{\mathrm{d}}$ & $922 \pm 2.0000^{\mathrm{d}}$ \\
10.0 & $830 \pm 1.6667^{\mathrm{f}}$ & $832 \pm 7.2188^{\mathrm{f}}$ \\
\hline
\end{tabular}

All column is mean \pm S.E. for respected concentrations in every group; column sharing the different letters (a,b,c,d,e and f) are significantly different with each other $(P \leq 0.05)$

\section{Discussion}

Continuous and repeated application of pesticides in the agricultural fields and also to the standing plantations will lead to the rise of many problems associated with soil health, disturbance to the soil micro flora which will directly have the impact on microorganism's populations and enzymatic imbalance. Currently, many of the pesticide are used to control the diseases and pests for the better crop yielding, unfortunately, most of the desired pesticides are used heavy or more than recommended doses. It is well understood that, pesticides have the ability to limit the population of soil bacteria (Shetti and Kaliwal, 2012). Correspondingly, pesticide stimulation on the enzyme activity and modulatory impact of pesticides have been previously reported by the number of researcher (Ismail et al. 1996; Sannino and Gianfreda, 2001).

Many of the experimental results of propiconazole persistent in soil and its toxicity have been reported. Singh and Dureja (2008) have shown a clear picture about the persistence of propiconazole in the soil. Additionally, the degradation rate of propiconazole was found slow in the paddy (Kim et al., 2002). Moreover, in vitro toxicity analysis of propiconazole on human cell lines authenticates its toxicity (Satapute and Kaliwal, 2015). Conversely, Yang et al. (2011) and 
Niewiadomska and Maruwka (2011) have reported that, propiconazole will have the greatest impact to inhibit the bacterial activity in the wetlands.

In the present study, it was observed that cellulase activity in red loamy and paddy soil was significantly decreased at the higher concentrations ( 7.5 and 10 $\mathrm{kg} / \mathrm{ha}$ ) and in lower doses ( 1 and $2.5 \mathrm{~kg} / \mathrm{ha}$ ) the activity of cellulase has been gradually increased, importantly the stimulatory activity was found at the $5 \mathrm{~kg} / \mathrm{ha}$. However, the invertase activity was influenced by the lower rate of concentrations ( 1 and $2.5 \mathrm{~kg} / \mathrm{ha}$ ). Meanwhile, the other rate of doses $(5,7.5$ and 10 $\mathrm{kg} / \mathrm{ha}$ ) of propiconazole were affected the invertase activity. More importantly, the accumulation of glucose formed by the sucrose in paddy soil was observed more than the red loamy soil. Conversely, invertase activity was evidenced by the accumulation of glucose during the incubation period, it was also observed that the soil, which was incubated for the 48 hrs after 10 days showed higher activity of invertase than the 24 hrs incubation.

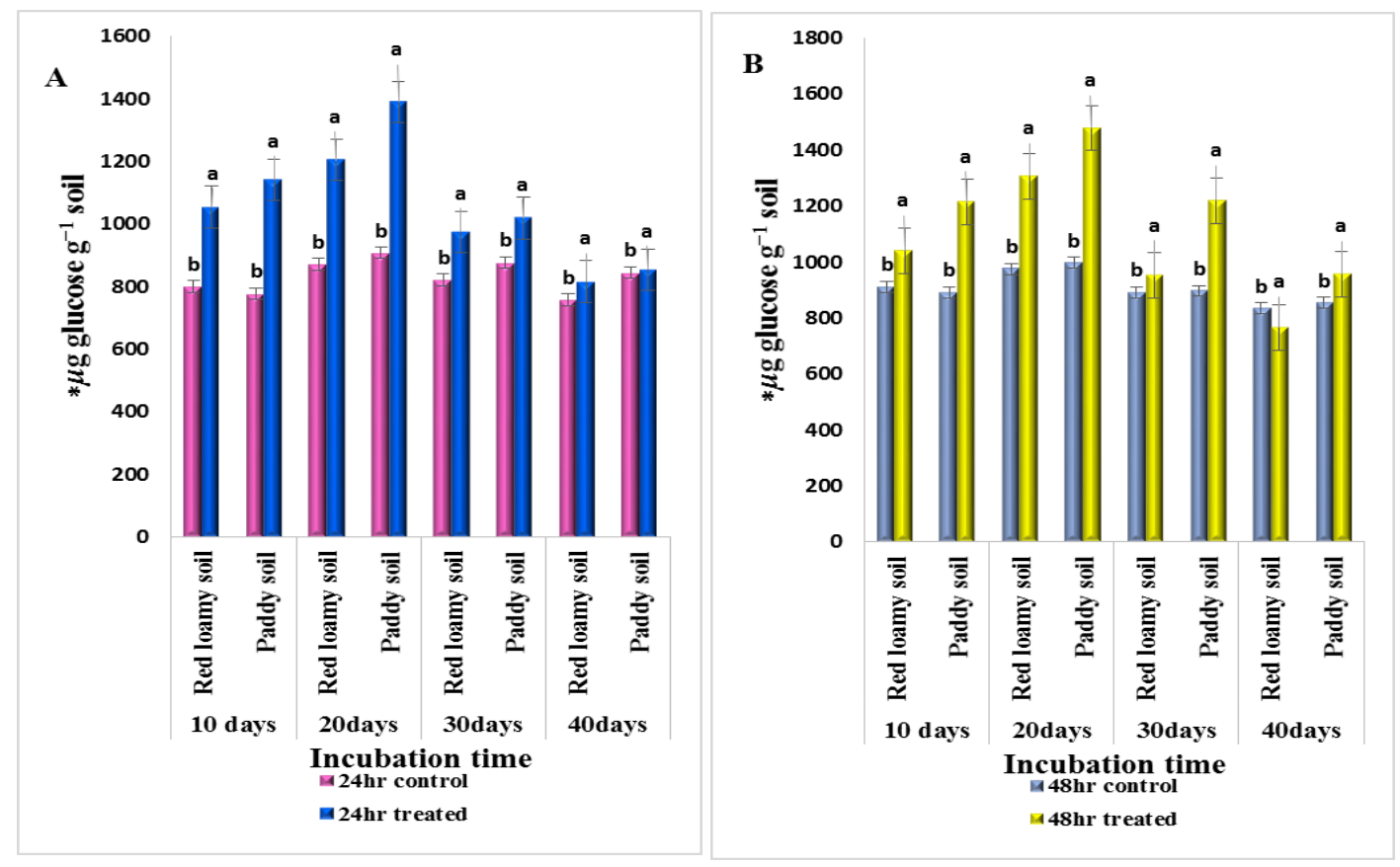

Fig. 2: Influence of propiconazole at $2.5 \mathrm{~kg} / \mathrm{ha}$ on invertase activity in red sandy loamy soil of ground nut and paddy soil after $24 \mathrm{hrs}$ (A) and $48 \mathrm{hrs}$ incubation (B) ${ }^{*} \mu \mathrm{g}$ of glucose/gram soil formed with $18 \mathrm{mM}$ sucrose after $10,20,30$, and 40 days. The data are the means \pm S.E. for each incubation period.

In support of our present study, Ramudu et al. (2011) have reported the similar trend of results explaining the impact of propiconazole on the ground nut soil enzyme activity, it was stated that the activity of cellulase and invertase was influenced by the accumulation of glucose. In the meantime the invertase activity was found higher than cellulase and prolonged incubation (40 days) soil treated with propiconazole does not show the stimulation and no quantifiable effect on the activity of enzymes. In contrast, the stimulatory impact of propiconazole on paddy soil was not investigated as is in the case of our study. The stimulatory application rate of propiconazole was found effective for the enzyme activity enhancement and it is proven in the present experimental results. Conversely, propiconazole is mainly used in the paddy fields (Yen et al., 2009). While associating the results of the present investigation to other literatures, a similar trend for the cellulase and invertase activity were seen, the activity of both the enzymes were influenced by the accumulation of glucose but an investigation on paddy soil was rarely under represented. However, similar observations were reported on the impact of endosulfan and quinalphos on paddy soil enzyme activity (Vijaya et al., 2012). Furthermore, our results seemed to the reliable with previously published literatures (Srinivasulu and Rangaswamy, 2006; Mohiddin et al., 2010). Although, carbendazim and chloramphenicol were found toxic to the invertase at the rate of $8 \mathrm{mg} / \mathrm{kg}$ (Hu et al., 2011). Contradictory observations have been reported by 
Mohiddin et al. (2013) saying that cellulase activity in red sandy loamy soil was decreased in the $5 \mathrm{~kg} / \mathrm{ha}$ by the effect flubendiamide and the stimulatory activity was found at the $2.5 \mathrm{~kg} / \mathrm{ha}$. Whereas, present results evidenced by the increase of cellulase activity at 5 $\mathrm{kg} / \mathrm{ha}$. Although, a similar trend of the decline phase of cellulase and enzyme activity was reported. Decline in the activity of cellulase is mainly because of propiconazole toxicity and such conditions will have the impact on soil microorganisms. Previously, comparable observations on cellulase activity were reported by the Katayama and Kuwatsuka (1991) and Madhuri and Rangaswamy (2002).

\section{Conclusion}

The results of the current investigation would draw attention on the propiconazole toxicity on cellulase and invertase activity. Cellulase activity was greatly increased in $5 \mathrm{~kg} / \mathrm{ha}$ followed by the $2.5 \mathrm{~kg} / \mathrm{ha}$ of propiconazole concentrations, but the naturally dropping down of cellulase activity was observed at the 7.5 and $10 \mathrm{~kg} / \mathrm{ha}$ in ground nut and paddy soil. When comparing the control in ground nut and paddy soil, invertase activity was shown the modulatory impact at $2.5 \mathrm{~kg} / \mathrm{ha}$. However, the activity was dramatically decreased at the $5,7.5$ and $10 \mathrm{~kg} / \mathrm{ha}$ doses of propiconazole. Overall, propiconazole at recommended application rates $(1,2.5$ and $5 \mathrm{~kg} / \mathrm{ha}$ ) will stance as healthier to soil enzymes and also to the soil microorganisms, more importantly the activity of both cellulase and invertase activity was higher in paddy soil than the red loamy soil of ground nut. Therefore, it indicates the microbial activity in the paddy soil is profoundly higher in the recommended doses.

\section{Conflict of interest statement}

Authors declare that they have no conflict of interest.

\section{Acknowledgement}

The authors are thankful to the Department of Biotechnology (DBT), Ministry of Science and Technology, Government of India, Delhi, for providing the instrumentation (BT/PR/4555/INF/22/126/2010 dated 30-09-2010) and bioinformatics infrastructure facility. Authors also thankful to the UGC-UPE fellowships and Post Graduate Department of Studies in Microbiology and Biotechnology, Karnatak University, Dharwad for providing the laboratory facilities.

\section{References}

Abrol, I. P., Sangar, S., 2006. Sustaining Indian agriculture - conservation agriculture the way forward. Curr. Sci. 91, 1020-2015.

Alef, L. K., Nannipieri, P., 1995. Methods in Applied Soil Microbiology and Biochemistry. Academic Press, Harcourt Bjace \& Company Publishers, London.

Alexander, M., 1977. An Introduction to Soil Microbiology. John Wiley and Sons, New York.

Cole, M. A., 1977. Lead inhibition of enzyme synthesis in soil. Appl. Environ. Microbiol. 33, 262-268.

Deng, S.P., Tabatabai, M.A., 1994. Cellulase activity of soils. Soil Biol. Biochem. 26, 1347-1354.

Ellert, B. H., Clapperton, M.J., Anderson, D. W., 1997. An ecosystem perspective of soil quality. In: Soil Quality for Crop Production and Ecosystem Health (Eds.: Gregorich, E. G., Carter, M. R.). Elsevier, Amsterdam. pp.115-141.

Elmholt, S., 1991. Side effects of propiconazole (Tilt $250 \mathrm{EC})$ on non-target soil fungi in a field trial compared with natural stress effects. Microb. Ecol. 22, 99-108.

Elmholt, S., 1992. Effect of propiconazole on substrate amended soil respiration following laboratory and field application. Pest. Sci. 34, 139-146.

Filipov, N. M., Lawrence, D. A., 2001. Toxicological highlight. Developmental toxicity of a triazole fungicide: consideration of interorgan communication. Toxicol. Sci. 62, 185-186.

Hu, Y., Dandan, W., Bin, D., Feifan, T., Baichuan, W., Hua, F., Yunlong, Y., 2011. Dissipation of carbendazim and chloramphenicol alone and in combination and their effects on soil fungal:bacterial ratios and soil enzyme activities. Chemosphere. 84, 634-641.

Ismail, B. S., Fugon, D., Omar, D., 1996. Effect of metolachlor on soil enzymes in Malaysian soil. J. Environ. Sci. Health. 31, 1267-1278.

Jackson, M. L., 1971. Soil Chemical Analysis. Prentice Hall, New Delhi, India.

Mohiddin, J. G., Srinivasulu, M., Subramanyam, K., Madakka, M., Meghana, D., Rangaswamy, V., 2013. Influence of insecticides flubendiamide and spinosad on biological activities in tropical black and red clay soils. 3 Biotech. 5(1), 13-21.

Johnson, C. M., Ulrich, A., 1960. Determination of moisture in plant tissues. Calif. Agri. Bull. No. 766, In: Soil and Plant Analysis for Tree Culture (Ed.: Wilde, S. A.). Obortage Publ. Co. Oxford and 
Bombay. pp.112-115.

Katayama, A., Kuwatsuka, S., 1991.Effects of pesticides on cellulose degradation in soil under upland and flooded conditions. Soil Sci. Plant Nutr. 37, 1-6.

Kim, I. S., Beaudette, L. A., Shim. J. H., Trevors. J. T., Suh. Y. T., 2002. Environmental fate of the triazole fungicide propiconazole in a rice-paddy-soil lysimeter. Plant Soil. 239, 321-331.

Madhuri, R. J., Rangaswamy, V., 2002. Influence of selected insecticides on phosphatase activity in groundnut (Arachis hypogeae L.) soils. J. Environ. Biol. 23, 393-397.

Mallik, M. K., Sharma, S. G., 2002. An in situ study on the activity of cellulase enzyme fractions during anaerobic digestion of agricultural wastes and weeds. Raj. J. Res. 12, 79-81.

Mohiddin, G. J., Srinivasulu, M., Madakka, M., Rangaswamy, V., 2010. Influence of insecticides on the activity of amylase and cellulase in groundnut (Arachis hypogaea L.) soil. Ecol. Environ. Conserv. 3, 383-388.

Nelson, N., 1944. A photometric adapatation of Somogyi method for determination of glucose. J. Biol. Chem. 153, 375-380.

Niewiadomska, Z., Maruwka, A. W., 2011. Impact of selected seed dressings on soil microbiological activity in spring barley cultivation. Fres. Environ. Bull. 20, 1252-1261.

Ramudu, A.C., Jaffer, M. G., Srinivasulu, M., Madakka, M., Rangaswamy, V., 2011. Impact of fungicides chlorothalonil and propiconazole on microbial activities in groundnut (Arachis hypogaea L.) soils. ISRN Microbiol. doi:10.5402/2011/623 404.

Sannino, F., Gianfreda, L., 2001. Pesticide influence on soil enzymatic activities. Chemosphere. 45, 417425.

Satapute, P. P., Kaliwal, B. B., 2015. In vitro toxicity screening of triazole fungicide propiconazole. Int. J. Recent Sci. Res. 6, 6525-6528.

Satapute, P., Kaliwal, B., 2016. Biodegradation of the fungicide propiconazole by Pseudomonas aeruginosa PS-4 strain isolated from a paddy soil. Ann. Microbiol. 66, 1355-1365.

Shetti, A. A., Kaliwal, B. B., 2012. Biodegradation of imidacloprid by soil isolates Brevundimonas sp. MJ15. I. J. Curr. Res. 4, 100-106.

Shetty, P. K., Magu, S. P., 1998. In vitro effect of pesticides on the carbon dioxide evolution and dehydrogenase activities in soil. J. Environ. Biol. 19, 141-144.

Shukla, A. K., 2000. Impact of fungicides on soil microbial population and enzyme activities. Acta Bot. Indica. 28, 85-87

Singh, N., Dureja, P., 2008. Synthesis and application of a novel molecularly imprinted polymer-coated stir bar for microextraction of triazole fungicides in soil. Bull. Environ. Contam. Toxicol. 82, 120-123.

Srinivasulu,M., Rangaswamy, V., 2006. Activities of invertase and cellulase as influenced by the application of tridemorph and captan to groundnut (Arachis hypogaea) soil. Afr. J. Biotechnol. 2, 175180.

Tu, C. M., 1981. Effects of pesticides on activities of enzymes and microorganisms in a clay soil. J. Environ. Sci. Health - Part B. 16, 179-191.

Vijaya, K. V., Srinivasulu, M., Jaffer, M. G., Padmini, A. R., Ramanamma, P., Naik, J. G., 2012. Effect of endosulfan and quinolphos on enzyme activities in paddy soil. Int. J. Res. Environ. SciTechnol. 2, 1016.

White, A. R., 1982. Visualization of cellulases and cellulose degradation. In: Cellulose and Other Natural Polymer Systems: Biogenesis, Structure, and Degradation (Eds.: Brown Jr. R.M.). Plenum Press, New York. pp.489-509.

Wightwick, A., Walters, R., Allinson, G., Reichman, S.M., Menzies, N.W., 2010. Environmental risks of fungicides used in horticultural production systems. In: Fungicides (Ed.: Carisse, O.). InTech, Reijka. pp.273-304.

Yang, C., Hamel, C., Vujanovic, V., Gan, Y., 2011. Fungicide modes of action and possible impact on non-target microorganisms. ISRN Ecol. dx.doi.org/ 10.5402/2011/130289

Yen, J. H., Chang, J. S., Huang, P. J., Wang. Y. S., 2009. Effects of fungicides triadimefon and propiconazole on soil bacterial communities. J. Environ. Sci. Health B. 44, 681-689.

\section{How to cite this article:}

Satapute, P., Kaliwal, B., 2017. Impact of propiconazole on soil enzymes activity in tropical red and paddy soils. Int. J. Curr. Res. Biosci. Plant Biol. 4(8), 93-100. doi: https://doi.org/10.20546/ijcrbp.2017.408.012 